\title{
Partnership Strategies for a Changing Society: A Comparative Review of the Literature
}

\author{
Debra A. Mims, Rhondda Waddell \\ Saint Leo University-University Campus, Florida, USA
}

\begin{abstract}
As the saying goes, "Perception is reality". To many minorities, the police are prejudiced toward people of color and unconcerned about providing services to their communities. From the police's perception minority neighborhoods are ambivalent and non-supportive of police efforts to combat crime in their community. As police community-relations have appeared to decline over the past years and tensions have exacerbated between the two; which perception is more accurate? Perhaps there is more than one answer with both sides needing to form a partnership and find ways to collaborate on strategies for a changing society. Negative perceptions threaten police and community relations and impact efforts to work together. Understanding both the cultural and ethnic differences of a community as well as the importance of discussing the implementation of crime control strategies are all elements, which can help change these negative perceptions. Police realize they alone cannot control crime and must truly enlist the aid of minority communities in this endeavor. As our society changes one thing is for certain, there are more questions than answers and we have to find a way to work together in order to be able to successfully meet the challenges that lie ahead. This literature review was conducted from two different perspectives - the perception of police and the community and the perceptions of community and the police.
\end{abstract}

Keywords: community policing, police trends, police reform, evidence based policing, Citizens Review Board, Neighborhood Watch, community perception, racism, police and race

\section{Introduction}

Current literature indicates the growing need to assess perceived police ineffectiveness and performance with neighborhood apathy and cynicism. Recent news and social media has emphasized the heightened levels of tension and violence that has permeated the television screens and front pages of newspapers across America, only succeeding in further eroding the public's reflection of police ineffectiveness and injustice (CNN, 2014; Corsaro, Frank, \& Ozer, 2014). Scrutiny of police actions as seen on YouTube, Facebook, Smartphones and the like is a reality that officers now face every day (Sullivan, 2016). FBI Director James Comey (2016) believes this type of media scrutiny has contributed to the police accountability movement in which officers are reluctant to engage in aggressive confrontations or crime-minimizing tactics in fear of receiving backlash and scrutiny from civilians. In fact, according to Director Comey (2016) officers are being less pro-active and more re-active due to the police accountability movement.

Enhancement of community oriented policing, diversity training and police-minority relations has brought

Debra A. Mims, Ph.D., Assistant Professor, Department of Criminal Justice, Saint Leo University-University Campus. Rhondda Waddell, Ph.D., Associate Professor, Department of Criminal Justice, Saint Leo University-University Campus. 
about continuity and change within the police departments. However, with the incorporation of additional training and community insight there seems to exist an even greater divisiveness among police and citizens than ever before. This literature review will begin with analyzing prior research on police perceptions of neighborhood crime and the perceived cynicism of the residents to assist with its own protection. Next, the literature will be explored to examine minority citizens' viewpoint with regards to strategies, which may be implemented to improve the relationship between the minority community and law enforcement. Lastly, this review will summarize the findings from the literature from both the police and minority community perceptions and recommend partnership strategies to improve the relationship between them.

\section{Methodology}

In this study, we focused on findings from a cross-sectional analysis of literature reviews conduced from two different perspectives. We concentrated on police officer's perceptions of community ambivalence and non-acceptance as well as the community's perception of police officers' prejudice and indifference. This study included a comparative review and examination of literature from various databases such as ProQuest, SAGE Premier, Taylor \& Francis Online, EBSCO and others, police journals, non-police journals, peer reviewed articles, books and police magazines as well as journalistic reports. Identifiers for this review included community policing, crime prevention, problem solving, police and race. The search limits were restricted to police initiatives implemented between 1992 and 2016.

In order to ascertain the minority community perceptions a meta-analysis of fifty articles was employed based on their discussion of the impact of community partnership organizations (Neighborhood Watch, Citizens Review Board), encouragement of improved police-community relations, minority experiences with police, minority perceptions of police and diversity within police agencies. We utilized post-structural theories to make sense of the data. In addition, axial coding and triangulation was also employed in the analysis of the data.

Studies were selected for inclusion in this review if they met the following requirements: (1) they encouraged police-citizen partnerships; (2) they fostered and improved communications and mutual understanding between police and citizens; (3) they promoted and facilitated cooperation and collaboration among police and community residents; (4) they promoted community responsibility and role concepts with police and community residents; and (5) they provided information and strategies to improve police-minority relationships (Peak \& Glensor, 2012). Articles not meeting these criteria were excluded.

The first research question examined in this literature review focused on police intervention strategies past, present and future and the establishment and enhancement of community relations between police and the community. The second research question focused on the perceived distrust and resentment community residents have for the police and the incorporation of partnership and collaboration strategies to facilitate cooperation from the community. Furthermore, this study encompasses a new approach on the public debate regarding the challenges relevant to implementation of a collaborative initiative between police and communities and their efforts to combat crime in their community.

\section{Policing Strategies in a Diverse Society: Review of the Literature}

Research has produced solid evidence on the relative effectiveness of a variety of policing strategies developed over the last 40 years (Roberg, Novak, Cordner, \& Smith, 2015; Casady, 2011). Studies have examined the effectiveness and ineffectiveness of previous police operational crime control methods, which at 
times, have exacerbated the tensions and violence between police and neighborhood residents, ultimately helping to shape the perceptions of indifference between the police and community residents (Kirk \& Papachristos, 2011). Law enforcement agencies must understand that building trust and respect is key in reducing tensions and handling crisis situations. However, when communities result to acts of violence and hostility, the gap between this divide only deepens and weakens, rather than improving, the us-versus-them mentality between the community and law enforcement.

New technologies and numerous resources are available for police administrators and officers to assist with identifying community problems, calls for service, crime mapping data, and problem solving techniques - just to name a few. A new era of information and policing is rapidly changing and moving the role of the police officer into an unpredictable future. Whether this new era will be positive or negative is debated by many, however, one thing is for certain, this new era of technological sophistication is making opportunities available for police agencies like never before.

Although technology is good and important for effective police operations it cannot take the place of daily interactions with citizens of the community. If the police fail to establish trust, order and respect from the community residents then the citizens in whom they are sworn to protect will avoid communicating with the police and therefore widen the gap of distrust. Review of the literature stresses the need for public cooperation and better communication with residents, as the police alone cannot prevent crimes (Bayley, 1994; Ferreira, 1996, Skolnick \& Bayley, 1991; Trojanowicz, 1994; US Bureau of Justice Assistance, 1994).

Appendix Table A1 presents examples of conventional, ideological and innovative police methods of policing from 1992 through 2016 intended to enhance police and community relationships, allow greater citizen input and reorganize police organizations in an attempt to provide better police efficiency (Sewell, 1999). Although police training and methodologies of police re-organization has improved immensely over the years, there still exists today a tremendous gap between the police and the community. The distrust, fear and disorder among both the police and the community residents are largely caused by ineffective communication (Hunter \& Barker, 2011). No matter how many re-organizations or strategies of community policing initiatives an agency utilizes, a partnership between the community and its police agency is essential. Community engagement begins with communication of honest, open discussions between the police and the residents.

As indicated in the many methodologies and varying degrees of implementation of policing over the years, police and community partnerships are complicated and diverse consortiums that require cooperation and not divergence. Many of the approaches listed are comprehensive and contain many multifaceted strategies that have many components in common. Evidence shows that each police strategy over the years has its merits of strengths and weaknesses as well as its ability to adapt to the needs of the communities in which they serve.

Hunter and Barker (2011) believe all citizens should be involved in policing the community in which they live, stressing that meaningful, two-way communication is important in building trust between police and the residents. Bottom line, the police and community residents must understand that neither is an entity unto its own and engagement and cooperation is the key to successful problem solving.

\section{Community Strategies in a Diverse Society: A Review of the Literature}

With the increasingly public negative interactions between the minority community and police the question of how to progress to a place of mutual respect, collaboration, and cooperation for the benefit of everyone is on the forefront of the minds of many. Research thus far has focused on the police encouraging 
general community cooperation however this has not moved us any closer to improving the relationship between police and the minority community. A review of the literature shows this is an area still in desperate need of research. Most studies available are dated and offer little insight to the current social and political climate in the United States. Current literature focuses on two major approaches of what can be transformed within police agencies; increasing minority officers or the overall legitimacy of officers (Brunson \& Gau, 2015; Tyler \& Fagan, 2008). In this section we will focus on some of the factors, which negatively impact perceptions minorities have of police officers patrolling minority communities.

It cannot be denied there is a gap between racial groups as to their perceptions of police. Historically the relationship between minority citizens and the police has been wrought with animosity and distrust. Minorities, particularly African-Americans, were taught to distrust the police as a matter of survival. During the Civil Rights Movements NAACP leaders and activists were beaten, shot, and terrorized. Vivid images of police being utilized in brutal ways to enforce segregation reinforced the lessons of the need to be wary of white police officers. With the legal death of Jim Crow a fresh wave of white terror and violence mounted towards those who supported dismantling of the prevailing system of the south. Images, which often included police, were broadcasted nationally and internationally by the media reaffirming the message of the police being the enemy of minorities. Unfortunately, this often remains the prevailing attitude of citizens living in poverty stricken communities and youth in those areas are being taught those long held beliefs (Lee, Steinberg, \& Piquero, 2010; Lee, Steinberg, Piquero, \& Knight, 2010). Recent events involving Trayvon Martin, Sandra Bland, Eric Garner, among others' deaths have reignited the sentiment of the need to be wary of the police within minority communities.

Upon a review of the literature it is widely accepted that positive attitudes towards the police will increase citizens' desire and willingness to cooperate with law enforcement (Renauer \& Covelli, 2011). One indicator of citizens' trust and satisfaction with the police is officers' respectfulness towards citizens (Gau, 2010). Researchers have shown males and minorities, notably African Americans, have more unfavorable views and are less likely to trust police than other citizens (Reisig \& Parks, 2000; Tyler \& Wakslak, 2004; Weitzer \& Tuch, 2005; Skogan, 2005). Research has also shown indirect contact is just as powerful, in some cases more important than, direct contact experiences on police perceptions. Brunson (2007) found young black males attitudes were negatively affected by indirect experiences with police. Mbuba (2010) found non-white college students viewed police more negatively than white students. In addition, male students were more likely to see police in a negative light and dissuaded their children or close family from becoming police officers.

Another factor to consider is the socioeconomic conditions of the communities officers were patrolling. Fagan and Davies (2000) note poverty and crime tend to reside in geographic pockets where minorities are disproportionately represented and these are the areas were police misconduct are most likely to occur. In high crime areas where police are seen as either underfunded, lacking proper resources, or lacking legitimacy mistrust of the police is reported at increased rates (Gau \& Bruson, 2010; Murphy, Hinds, \& Fleming, 2008; Brunson, 2007).

Tyler (2008) defines legitimacy as:

.... a feeling of obligation to obey the law and to defer to the decisions made by legal authorities. Legitimacy, therefore, reflects an important social value, distinctfrom self-interest, to which social authorities can appeal to gain public deference and cooperation. In past research, legitimacy has been measured using items reflecting the perceived obligation to obey legal authorities, as well as trust and confidence in authorities. (p. 235) 
The concept of legitimacy among police agencies is seen as one of the core factors as to why minority communities mistrust law enforcement. Legitimacy is further defined by Walker and Katz (2013) as "the belief that the police as a social institution are acting properly and effectively, and deserve public support" (p. 377). The perceived lack of legitimacy directly impacts citizens' perceptions of police officers. While the issue of legitimacy is of important concern to minority communities it is a matter of consternation to all Americans.

Research has been committed to dissecting the importance of perceptions and attitudes towards the police within minority-community and police relationships. When examining the literature for strategies to improve the relations between the minority-community, specifically, and the police the prevailing tactic was to increase minority representation within the police force. The officer-race hypothesis led many law enforcement agencies to hire more African-Americans, albeit some by force, in an attempt to target the issue of the strained relationship between the two (Weitzer, 2000). The assumption was hiring more Black officers would reduce the animosity as Black officers and Black citizens would better relate to one another (Brunson \& Gau, 2015). However, what was not considered was the complex dynamics of being a minority officer trying to be a successful officer and needing to assimilate into the police culture. Black citizens reported they were faced with Black officers engaging in police misconduct and using racial epithets as well. In another study Black officers reported they were often seen as "traitors" by Black citizens and their authority was often challenged leaving them to feel more pressure to exert their authority (Brunson \& Gau, 2015).

Legitimacy is seen as the police acting within the best interests of the citizens they are serving therefore earning public support and increasing the commitment to cooperate with law enforcement. In high poverty/crime areas resources are often limited leading minority citizens to perceive police as lacking legitimacy. Although widely accepted that positive attitudes improve the perception of legitimacy research has revealed there is a distinctly negative perception of the police within the minority community, particularly amongst males. Thus far the dominant strategy employed by law enforcement to combat this perception has been to increase minority representation within police agencies. This strategy has not resulted in increased positive perceptions of the police within the minority community and in some cases has backfired altogether.

\section{Limitation and Suggestions for Future Research}

A limitation in this comparative review of the literature was the paucity of police officer's perceptions of citizens' ambivalence and support in the effort to reduce crime in their community. The observed trend in the published material was towards a more bureaucratic, philosophical and tactical dimension of policing and reorganization of police agencies. The research on what individual officers can do to change their individual perceptions of the community and achieve mutual respect for one another was meager.

In addition, the number of literature articles discussing the role of citizens in the community involved in the problem solving process and how residents can better assist the police in their efforts to reduce crime in their communities and improve police-community relations was even more limited and inadequate. Glaringly absent from the literature is representation from the minority community with regards to improving perceptions of the police or engagement in the development of potential strategies for improving minority community/police relations.

It is imperative to further investigate the inclusion of both the minority citizens and officers voices in the development of partnership strategies between the two. In addition future research should also seek to ascertain the minority-community/police ideas on where to focus initial efforts for improving the relationship. Future 
research should seek to develop strategies inclusive of their input to best address the negative perceptions thereby increasing citizens'cooperation.

\section{References}

Alexander, M. (2012). The new Jim Crow: Mass incarceration in the age of colorblindness. New York: The New Press.

Bailey, K. D. (1994). Sociology and the new systems theory, toward a theoretical synthesis. New York: State University of New York.

Balko, R. (2010). Beyond Bars: A new project has conservatives thinking more seriously about crime. Reason.

Brunson, R. K. (2007). Police don't like black people: African-American young men's accumulated police experiences. Criminology \& Public Policy, 6(1), 71-101.

Brunson, R., \& Gau, J. (2015). Officer versus Macro-level context: A test of competing hypotheses about black citizens' experiences with and perceptions of black police officers. Crime and Delinquency, 61(2), 213-242.

Cao, L., Frank, J., \& Cullen, F. T. (1996). Race, community context and confidence in the police. American Journal of Police, $15(1), 3-22$.

Casady, T. (2011). Police legitimacy and predictive policing. Geography \& Public Safety, 2(4). 1-2.

Clarke, R. V., \& Felson, M. (1993). Routine activity and rational choice, advances in criminology theory. New Brunswick: Transaction Publishers, Inc.

CNN Headline News. (2014). Department of Justice admonishes Ferguson police. Retrieved May 19, 2016, from http://www.cnn.com/2014/09/26/us/ferguson-michael-brown-protests/

Corsaro, N., Frank, J., \& Ozer, M. (2014). Perceptions of police practice, cynicism of police performance, and persistent neighborhood violence: An intersecting relationship. Journal of Criminal Justice, 43, 1-11.

Edwards, C. (2005). Changing policing theories for 21st century societies (2nd ed.). Leichhardt, Australia: Federation Press.

Fagan, J., \& Davies, G. (2000). Street stops and broken windows: Terry, race, and disorder in New York City. Fordham Urban Law Journal, 28, 457-504.

Ferreira, B. (1996). The use and effectiveness of community policing in a democracy. National Institute of Justice National Criminal Justice Reference Service, Washington, D.C

Fuller, C. (2016). FBI Director's statements about "Ferguson Effect" reinforce desperate need for police accountability.

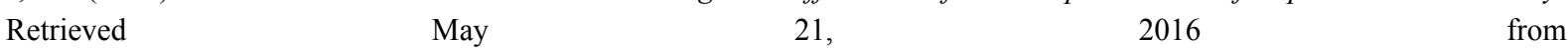
http://www.advancementproject.org/news/entry/fbi-directors-statements-about-ferguson-effect-reinforce-desperate-need-for

Gau, J. M. (2010). A longitudinal analysis of citizens' attitudes about police. Policing: An International Journal of Police Strategies \& Management, 33(2), 236-252.

Gau, J. M., \& Brunson, R. K. (2010). Procedural justice and order maintenance policing: A study of Inner-City Young Men's perceptions of police legitimacy. Justice Quarterly, 27(2), 255-279.

Goldstein, H. (1990). Problem-oriented policing. New York: McGraw-Hill.

Greene, J. R. (1993). Community policing in the United States: Historical roots, present practices and future requirements. In D. Dolling, \& T. Feltes (Eds.), Community policing: Comparative aspects of community oriented police work (Band 5). Holzkirchen, Germany: Felix Verlag.

Hunter, R., \& Barker, T. (2011). Police community relations and the administration of justice. Upper Saddle River, NJ: Prentice Hall.

Jackson, J., Bradford, B., Hough, M., Myhill, A., Quinton, P., \& Tyler, T. R. (2012). Why do people comply with the law?: Legitimacy and the influence of legal institutions. British Journal of Criminology, 52(6), 1051-1071.

Jeffrey, C., \& Zahm, D. (1993). Crime prevention through environmental design, opportunity theory, and rational choice models. Routine Activity and Rational Choice: Advances in Criminological Theory, 5, 323-350.

Kirk, D. S., \& Papachristos, A. V. (2011). Cultural mechanisms and the persistence of neighborhood violence. The American Journal of Sociology, 116, 1190-1233.

Lee, J. M., Steinberg, L., \& Piquero, A. R. (2010). Ethnic identity and attitudes toward policing among African American juvenile offenders. Journal of Criminal Justice, 38, 781-789.

Lee, J. M., Steinberg, L., Piquero, A. R., \& Knight, G. P. (2010). Identity-linked perceptions of the police among African American juvenile offenders: A developmental perspective. Journal of Youth and Adolescence, 40(1), 23-37.

Lim, H. Y. (2015). Social modeling effects on perception of the police. Policing: An International Journal of Police Strategies \& Management, 38(4), 675-689. 
Mbuba, J. M. (2010). Attitudes toward the police: the significance of race and other factors among college students. Journal of Ethnicity in Criminal Justice, 8(3), 201-215.

Moffat, R. (1983). Crime prevention through environmental design-A management perspective. Canadian Journal of Criminology, 25(4), 19-31.

Murphy, K., Hinds, L., \& Fleming, J. (2008). Encouraging public cooperation and support for police. Policing and Society,18(2), 136-155.

National Criminal Justice Reference Service. (1992). Retrieved May 22, 2016, from https://www.ncjrs.gov/App/Publications/abstract.aspx?ID=144727

Newton, S., \& Welch, T. (2013). Understanding criminal evidence: A case method approach. Frederick MO: Wolters Kluwer.

O'Grady, W. (2011). Crime in Canadian context: Debates and controversies (2nd ed.). ON: Oxford University Press.

Peak, K., \& Glensor, R. (2012). Community policing and problem solving: Strategies and practices. Upper Saddle River, NJ: Prentice Hall.

Pearsall, B. (2010). Predictive policing: The future of law enforcement? Retrieved from http://www.nij.gov/journals/266/pages/predictive.aspx

Reisig, M. D., \& Parks, R. B. (2000). Experience, quality of life, and neighborhood context: A hierarchical analysis of satisfaction with police. Justice Quarterly, 17(3), 607-629.

Renauer, B. C., \& Covelli, E. (2011). Examining the relationship between police experiences and perceptions of police bias. Policing: An International Journal of Police Strategies \& Management, 34(3), 497-514.

Rengifo, A. F., \& Fowler, K. (2015). Stop, question, and complain: Citizen grievances against the NYPD and the opacity of police stops across New York City Precincts, 2007-2013. Journal of Urban Health J Urban Health, 93(S1), 32-41.

Roberg, R., Novak, K., Cordner, G., \& Smith, B. (2015). Police \& society (6th ed.). New York, NY: Oxford University Press.

Romero, J. (2015). Evidence-based policing advantages, disadvantages, impacts. Panmore Institute.

Sewell, J. (1999). Controversial issues in policing. Needham Heights, MA: Allyn and Bacon.

Skogan, W. G. (2005). Citizen satisfaction with police encounters. Police Quarterly, 8(3), 298-321.

Skolnick, J. H., \& Bayley, D. H. (1991). The new blue line. In C. B. Klockars, \& S. D. Mastrofski (Eds.), Thinking about police: Contemporary readings (2nd ed.). New York: McGraw-Hill Publishing Company.

Sullivan, D. (2016). Takedown in teen arrest "no big deal". Tampa Bay Times.

Trojanowicz, R. C. (1994). The future of community policing. In D. P. Rosenbaum (Ed.), The challenge of community policing: Testing the promises. Thousand Oaks, CA: Sage Publications.

Tyler, T. R., \& Wakslak, C. J. (2004). Profiling and police legitimacy: Procedural justice, attributions of motive, and acceptance of police authority. Criminology, 42(2), 253-281.

Tyler, T., \& Fagan, J. (2008). Legitimacy and cooperation: Why do people help the police fight crime in their communities? Ohio State Journal of Criminal Law, 6(1), 231-275.

U.S. Department of Justice. National Institute of Justice. (1994). 25 Years of Criminal Justice Research: The National Institute of Justice. Washington, DC: Author.

Walker, S., \& Katz, C. (2013). The police in America: An introduction. New York, NY: McGraw Hill Publications.

Weitzer, R. (2000). White, Black, or blue cops? Race and citizen assessments of police officers. Journal of Criminal Justice, 28, 313-324.

Weitzer, R. (2002). Incidents of police misconduct and public opinion. Journal of Criminal Justice, 30, 397-408.

Weitzer, R., \& Tuch, S. (2005). Determinants of public satisfaction with the police. Police Quarterly, 8(3), 279-297. 
Appendix

Table A1

Police Methods of Community Policing 1992-2016

\begin{tabular}{|c|c|c|c|}
\hline Year & Police method & Intention & Criticism \\
\hline 1992 & $\begin{array}{l}\text { Crime Prevention Through } \\
\text { Environmental Design (CPTED) }\end{array}$ & $\begin{array}{l}\text { "Emphasized the use of the physical } \\
\text { environment to control behavior" } \\
\text { (Jeffrey, 1993, p. 330) }\end{array}$ & $\begin{array}{l}\text { Research demonstrates that offenders } \\
\text { cannot be literally prevented from } \\
\text { committing crimes by using CPTED } \\
\text { as it deters rather than conclusively } \\
\text { "prevents" behavior (O'Grady, 2011) }\end{array}$ \\
\hline 1992 & Situational Crime Prevention & $\begin{array}{l}\text { Increase the risk and increase the } \\
\text { effort by target hardening and } \\
\text { reducing the opportunities }\end{array}$ & $\begin{array}{l}\text { "situational variables might } \\
\text { determine the timing and location of } \\
\text { offending, but reducing opportunities } \\
\text { at a particular time and place would } \\
\text { result simply in displacement of } \\
\text { offending to other times, places, or } \\
\text { crimes, with no net reduction in } \\
\text { crime" (Clarke \& Felson, } 1993, \text { p. 4) }\end{array}$ \\
\hline Mid 1990s & $\begin{array}{l}\text { Community Oriented Policing and } \\
\text { Problem Solving Program (COPPS) }\end{array}$ & $\begin{array}{l}\text { COPPS addresses the causes of } \\
\text { crime, encourages community } \\
\text { participation and cooperation with } \\
\text { police, and makes better use of } \\
\text { existing community resources. } \\
\text { (National criminal justice reference } \\
\text { service, 1992). }\end{array}$ & $\begin{array}{l}\text { The community will have to become } \\
\text { involved in the policy of the police in } \\
\text { handling local problems before it can } \\
\text { work. Greene (1993) noted that one } \\
\text { of the strategic issues that was not } \\
\text { resolved yet is the effort towards } \\
\text { community renewal and what the role } \\
\text { of the police should be. }\end{array}$ \\
\hline Late 1990s & $\begin{array}{l}\text { Problem Oriented Policing-POP } \\
\text { (identification, analysis, response, } \\
\text { and evaluation) } \\
\text { AKA: CAPRA (clients, acquiring \& } \\
\text { analyzing information, partnerships, } \\
\text { response, assessment) and SARA } \\
\text { (scan, analyze, respond \& assess). }\end{array}$ & $\begin{array}{l}\text { Similar to COPPS but attempts to } \\
\text { engage productively with the } \\
\text { community in a narrower effort to } \\
\text { deal with specific community } \\
\text { problems (Goldstein, 1990). }\end{array}$ & $\begin{array}{l}\text { The role of POP is only concerned } \\
\text { with crime and the enforcement of } \\
\text { law which has restrictions and limits } \\
\text { only to a certain extent to prevent } \\
\text { crime (Goldstein, 1979). Goldstein } \\
\text { argued that a new strategy needed to } \\
\text { be developed as most crimes are in } \\
\text { the same place and committed by the } \\
\text { same individuals. }\end{array}$ \\
\hline Early 2000s & $\begin{array}{l}\text { Computerized Statistics Program } \\
\text { (COMPSTAT) }\end{array}$ & $\begin{array}{l}\text { Incorporates both POP and COPPS } \\
\text { by enhancing and incorporating the } \\
\text { best of both, the latest elements of } \\
\text { computer technology and total quality } \\
\text { management (TQM). }\end{array}$ & $\begin{array}{l}\text { Officers may be discouraged from } \\
\text { taking crime reports in order to create } \\
\text { a false appearance of a reduction of } \\
\text { community problems. According to } \\
\text { journalist Radley Balko, "ome ... } \\
\text { reports suggest the program needs } \\
\text { some tweaking to guard against the } \\
\text { twin dangers of unnecessary police } \\
\text { harassment and underreporting of } \\
\text { serious crimes" }\end{array}$ \\
\hline Mid 2000s & Intelligence Led Policing & $\begin{array}{l}\text { Incorporates both real time analysis } \\
\text { and intelligence led analysis for } \\
\text { deployment, interception and } \\
\text { elimination thus, helping prevent } \\
\text { crime by creating a police force that } \\
\text { is more efficient with its resources. }\end{array}$ & $\begin{array}{l}\text { According to Newton and Welsh } \\
(2013) \text { ILP blurs the lines between } \\
\text { national security and domestic } \\
\text { policing, risking the same perils } \\
\text { tarnished policing in the past, such as } \\
\text { political interference, violating civil } \\
\text { liberties, and a greater potential for } \\
\text { the abuse of police power with the } \\
\text { increased secrecy that intelligence } \\
\text { work entails. }\end{array}$ \\
\hline $\begin{array}{l}\text { Mid-late } \\
\text { 2000s }\end{array}$ & Evidence Based Policing (EBP) & $\begin{array}{l}\text { According to Sherman (2013) } \\
\text { Evidence-based policing involves } \\
\text { looking at police methods and } \\
\text { strategies to see which practice is }\end{array}$ & $\begin{array}{l}\text { Evidence-based policing can be } \\
\text { disadvantageous in that it consumes } \\
\text { more time on the part of the law } \\
\text { enforcers (Romero, 2015). Research }\end{array}$ \\
\hline
\end{tabular}




\begin{tabular}{|c|c|c|c|}
\hline & & $\begin{array}{l}\text { most cost effective in deterring crime } \\
\text { by conducting evaluations on } \\
\text { effective research and data. EBP } \\
\text { helps to balance the publics' safety, } \\
\text { community service needs, available } \\
\text { funds and taxpayer expectation. It } \\
\text { helps communities focus on } \\
\text { meaningful, achievable public safety } \\
\text { outcomes without breaking their } \\
\text { budgets (Bueermann, 2012). } \\
\end{array}$ & $\begin{array}{l}\text { involves higher costs for collecting } \\
\text { evidence and conducting the research } \\
\text { (Panmore Institute, 2016). }\end{array}$ \\
\hline Late $2000 \mathrm{~s}$ & $\begin{array}{l}\text { Predicative Policing-Billed as the } \\
\text { Future of Law Enforcement }\end{array}$ & $\begin{array}{l}\text { Spin-off of ILP - using intelligence } \\
\text { led and analyses to not only react to } \\
\text { incidents quickly but to be able to use } \\
\text { data to anticipate incidents, allowing } \\
\text { officers to be more reactive and } \\
\text { respond more effectively to future } \\
\text { crime. }\end{array}$ & $\begin{array}{l}\text { According to Russell Porter, director } \\
\text { of the State of Iowa Intelligence } \\
\text { Fusion Center, addressing privacy } \\
\text { and civil liberty issues is of } \\
\text { paramount concern when } \\
\text { implementing predicative policing } \\
\text { measures. "We have a solemn } \\
\text { obligation and a strategic imperative } \\
\text { for the success of predictive policing } \\
\text { to put privacy, civil rights and civil } \\
\text { liberties in the forefront from the } \\
\text { outset" (as quoted by Beth Pearsall, } \\
\text { 2010). }\end{array}$ \\
\hline
\end{tabular}

